that the term 'Mummy' appeared to exclude other familial relationships and might cause legitimate upset to friends and more distant relatives of the deceased. He further noted that the granting of the application might cause pastoral difficulties in the parish as there had been previous applications seeking similar inscriptions which had (like this application) been properly refused by the incumbent. The chancellor observed that none of those previous applicants had sought a faculty and that his discretion could not be fettered by the decision of such applicants not to petition the consistory court. The chancellor, after encouraging the petitioner to reconsider her choice of words, noted the exceptional nature of the case and granted the faculty sought should the petitioner pursue it. The faculty was subject to the lodging at the registry of the signatures of all of the deceased's children, grandchildren, great-grandchildren and siblings signifying their consent. The chancellor made plain that no precedent for such an inscription was being established either within the particular churchyard or in the diocese or generally. [RA]

\title{
Re St Mary, White Waltham
}

Oxford Consistory Court: Bursell Ch, December 2009 Churchyard - building - consultation - planning permission

The judgment followed on from an interim hearing and unsuccessful application for leave to appeal to the Court of Arches noted at (2010) 12 Ecc LJ 122. The interim order permitted a small amount of work to be carried out to prevent the lapse of planning permission. There were three parties opponent and the chancellor also took into account the views of a number of informal objectors. The chancellor reviewed the law on consultation, the burden of proof, the relationship between local planning authorities and the consistory courts, the Bishopsgate questions, erection of buildings in burial grounds and cost. He followed the pattern of other courts in holding that when planning permission had been granted the court was able to accept the reasoned decisions of that authority unless they were shown by cogent evidence to be wrong. In addressing the Bishopsgate questions the chancellor found that the current arrangements for children's activities in the church were not ideal, taking place at some distance from the church with consequent concerns about the integration of children into the life of the church and of safety getting to and from the church. Despite the relatively small number of children presently attending Sunday school the chancellor held that there was a very real need for proper provision for children's work if that number were to increase. $\mathrm{He}$ held that this increase was necessary for the continued mission of the church, 
that the proposed building was necessary and would not adversely affect the character of the church building. The faculty was granted. [WA]

doi:10.1017/So956618X10000335

\section{Ladele v Islington Borough Council and Liberty}

Court of Appeal: Lord Neuberger of Abbotsbury MR, Dyson and Smith LJJ; December 2009

Registrar - discrimination - civil partnerships

The appellant, a registrar of marriages, sought to reverse the decision of the Employment Appeals Tribunal and reinstate the decision of the Employment Tribunal ${ }^{1}$ that her employer was guilty of discrimination (both direct and indirect) under the Employment Equality (Religion or Belief) Regulations 2003, SI 2003/1660, by compelling her to register civil partnerships, to which she has an objection based on her religious beliefs. The local authority sought to show that it had no option but to compel the appellant to register such partnerships. In dismissing the appeal the court upheld the judgment of the EAT and judged that the actions of the council were proportionate to the legitimate aim of implementing their 'Dignity for All' policy, which was aimed not only at countering discrimination in the wider community, but also within the departments of the council. Furthermore, the appellant could not claim breach of her rights under Article 9 of the European Convention on Human Rights, as the legitimate aim of the council could not be overridden by her desire that her religious views be respected. Liberty, who had intervened, argued, and the court accepted, that a registrar who is prepared to perform marriages discriminates if he refuses to perform civil partnerships (Equality Act (Sexual Orientation) Regulations 2007 , SI 2007/1263); that the regulations themselves state that, for their purposes, marriage and civil partnership are not materially different; that a civil partnership is a public service and the council and registrar public bodies; and that the council could be liable for the registrar's refusal, especially as she had been designated as a civil partnership registrar. The court noted that if a registrar had not been designated as a civil partnership registrar then questions under the 2007 regulations would not arise. However, the fact that she was so registered did not amount to direct or indirect discrimination against her by the council. [WA] 